\title{
THE SHARE OF XEROTHERMIC SPECIES IN VASCULAR FLORA OF THE CITY OF LUBLIN (POLAND)
}

\author{
Anna Rysiak \\ Department of Ecology, Maria Curie-Skłodowska University \\ Akademicka 19, 20-033 Lublin, Poland \\ e-mail: anrysiak@tlen.pl
}

Received: 27.09.2011

\begin{abstract}
The purpose of this study is to present the distribution and characteristics of xerothermic flora located within Lublin $\left(51^{\circ} 08^{\prime}-51^{\circ} 18^{\prime} \mathrm{N}\right.$ and $\left.22^{\circ} 27^{\prime}-22^{\circ} 41 \mathrm{E}\right)$. The data on this flora have been derived from the literature and herbarium collections as well as they were collected during field research conducted in 2002-2009.

Family affiliation, life forms, geographical-historical groups, the degree of synanthropization of species and habitat, categories of threat are discussed in this paper. 107 xerothermic species belonging to 26 families and 70 genera were reported from the area of Lublin. The number constitutes $10 \%$ of the city's flora. The most numerous are plants from the classes Festuco-Brometea (70 species), Trifolio-Geranietea sanguinei (21) and Rhamno-Prunetea (16). All extinct species (8) belong to the class Festuco-Brometea. The analysis of the spectrum of life forms indicates that the biggest share in the flora of Lublin was observed in the group of hemicryptophytes ( 57 species) and phanerophytes (14). The native species (103) dominate over the group of alien ones (4 species). The group of xerothermic plants comprises 21 legally protected and endangered species. Xerothermic plants exhibit a mosaic distribution in the area of Lublin. The frequency (measured as the presence of a species in a study unit, one ATPOL square) ranged from 1 to 44 species. Two main features of the analyzed area seemed to be responsible for species distribution: the value of the Real Hemeroby Index (RIH) and the history of the flora.
\end{abstract}

Key words: xerothermic flora, urban flora, anthropopressure, Lublin city, eastern Poland

\section{INTRODUCTION}

A big city is an unusual phenomenon of culture, sociology, and economics, but also of flora and vegetation. The plant cover of a city is related to ecological and historical human activity. The flora of urban areas consist of two groups of species: hemerophobes - native or permanently naturalized alien species which are withdrawing from the given area under the influence of human activity, and hemerophiles - native species and a great part of archaeophytes and kenophytes spreading under the influence of human's activity showing permanent apophytic tendencies (J a ckowiak, 1990).

So far, data on xerothermic plants in Lublin and in the macroregion surrounding Lublin have been mainly published by Fijałkowski (1954), Fija kowski and Izdebski (1957) and Izdebski (1958). The papers mentioned above describe stands of xerothermic plants in the NE part of Lublin (Rudnik district). The xerothermic patches investigated were classified into three syntaxa: the associations Carex humilis-Inula ensifolia and Festuca vallesiaca-Erysimim crepidifolium from the class Festuco-Brometea, and Prunetum fruticosae communities. The authors recorded 57 xerothermic species in the area of Rudnik. They emphasize a large admixture (14 species) of forest species from the class Querco-Fagetea in the shrub community with Cerasus fruticosa, which may indicate progressing succession. The communities were reported from steep slopes of loess gullies and the Bystrzyca River valley. The communities with Carex humilis and Festuca vallesiaca were found on slopes with a southerly aspect, whereas the shrub communities were found on the flat tops of the loess plateaus and slopes with a northern exposure. The analysis of the edaphic conditions demonstrated that both communities occured on $\mathrm{CaCO}_{3}$-rich loess soils. The stands of xerothermic species and vegetation in Lublin city are usually found on loose loam calcareous soils rich in $\mathrm{CaCO}_{3}$ (D e n i s ow et al. 2008). 
Investigations of the flora and vascular plant communities of railway areas in the western part of the Lublin Upland (W r z e s i e ń and Ś w i ę s, 2006) showed that these areas are substitute habitats for xerothermic vegetation. The xerothermic flora comprised 54 species, including 27 from the class Festuco-Brometea, 13 from Rhamno-Prunetea, and 14 from the class Trfolio-Geranietea sanguinei. The authors described 11 xerothermic communities within the railway infrastructure of Lublin (railway stations, rails, embankments, rail edges); 4 communities were classified as Festuco-Brometea, 6 as Trifolio-Geranietea sanguinei, and 1 as the class Rhamno-Prunetea.

The aim of the study was to evaluate the role and share of the group of xerothermic species in the contemporary flora of the city of Lublin. The more specific goals can be formulated in the following way:

Analysis of the current spatial distribution of xerothermic species in the territory of Lublin.
Compilation of features of the investigated plant group (habitat preferences, geographical-historical status, life forms, response to the environmental changes in the Lublin area).

Comparison of the present share of this group of plants with the historical data.

\section{MATERIALS AND METHODS}

\section{The characteristics of the study area}

The city of Lublin, Poland, in its present administrative boundaries covers the area of $148 \mathrm{~km}^{2}$ and is situated between $51^{\circ} 08^{\prime}-51^{\circ} 18^{\prime} \mathrm{N}$ and $22^{\circ} 27^{\prime}-$ $22^{\circ} 41^{\prime} \mathrm{E}$, having a population of 300,000 permanent residents. It is the capital of the Lublin province ( $\mathrm{S} \mathrm{t}$ o $\mathrm{chlak}, 1999)$. The city is located in the central-northern part of the macroregion of Lublin (Lublin-Lviv) Upland on the border of four macroregions: Nałęczów Plateau, Bełżyce Plain, Świdnik Plateau and Giełczewska Elevation (K o n d r a c k i, 2009) (Fig. 1.).

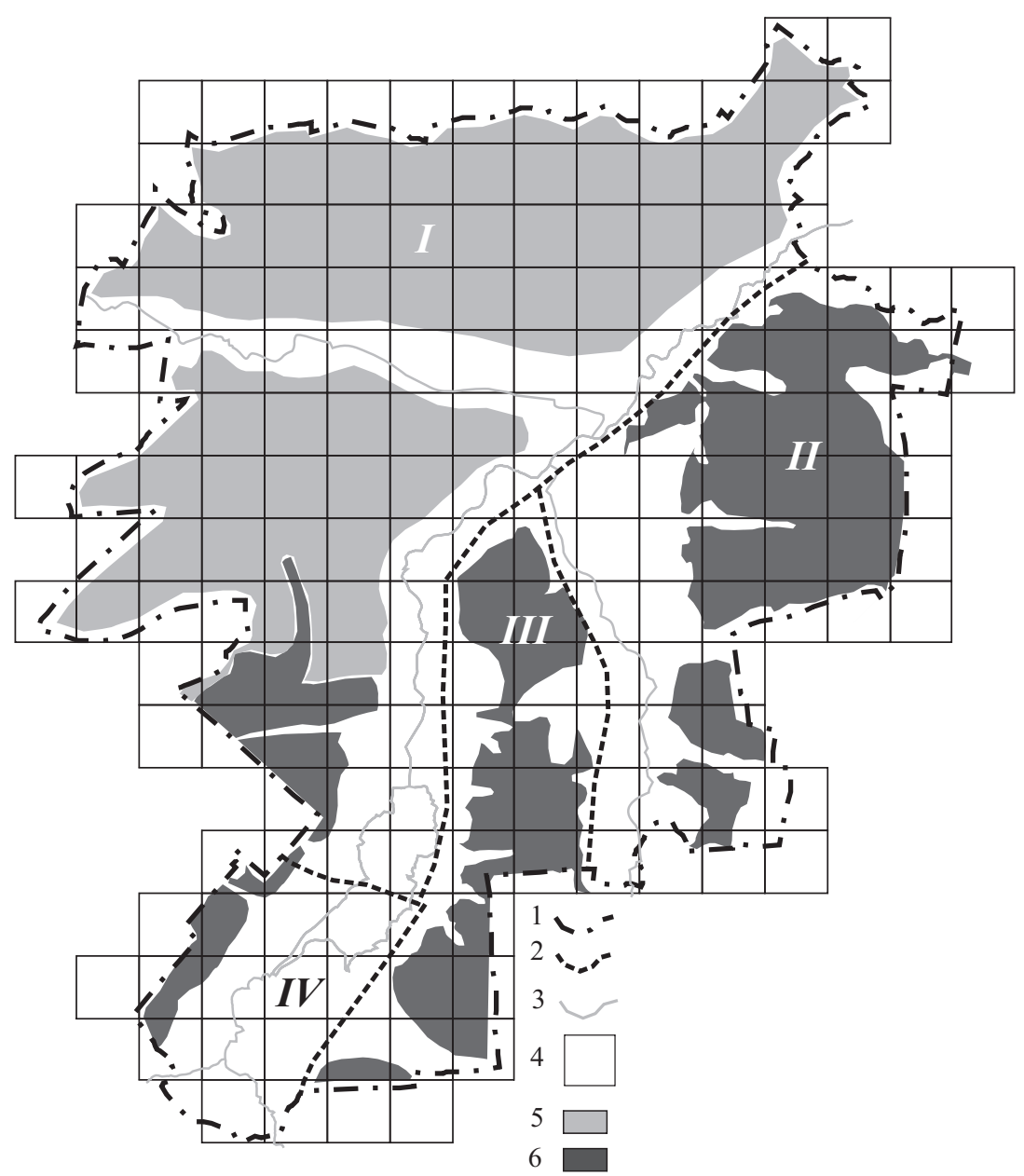

Fig. 1. Map of the city of Lublin, Poland, against the background of ATPOL grid (1 km x $1 \mathrm{~km}): 1$ - administrative city boundaries; 2 - boundaries of physico-geographical macroregions of Lublin Upland: I - Nałęczów Plateau, II - Świdnik Plateau; III - Giełczewska Elevation, IV - Bełżyce Plain; 3 - rivers and water bodies; 4 - square of ATPOL grid (1km x 1km); some Quaternary sediments: 5 - loess cover; 6 - loess-like and clay covers. 
The city of Lublin is characterized by fairly specific climatic properties (Zinkiewicz and Warakomski, 1959; K a szewski et al. 1995). The average annual air temperature is $7.9^{\circ} \mathrm{C}$. The coldest month is January and the warmest one July, with their average air temperatures of $3.6^{\circ} \mathrm{C}$ and $18.6^{\circ} \mathrm{C}$, respectively. The average annual precipitation is $556 \mathrm{~mm}$. The highest amount of precipitation is recorded in July (ca. $77.0 \mathrm{~mm}$ ), the lowest one in January (ca. $29.6 \mathrm{~mm}$ ). The average annual insolation is 4.5 hours per day. Snow cover persists for $60-80$ days per year. The average growing season in the Lublin area lasts 209 days (S t o chlak, 1999).

Within the area of Lublin, the basic Quaternary substratum is composed of loess and loess-like and clay covers (Chałubińs ka and Wilgat, 1954). The former sediments predominate in the western part and the latter ones in the southern part of the city. The borderland between these covers is the Bystrzyca river valley in the general outline (M a r u z c z a k, 1958; Haras imiuk and Henkie 1, 1982).

Different soil types are found within the Lublin area (Turski et al. 1993). The prevalent types are clay-dusty and sandy-dusty brown and grey-brown soils. In the valleys of the river system, there is a mosaic of alluvial and black soils, sporadically marshy and peat soils. The soils within Lublin's densely built-up areas are usually highly anthropogenically degraded soils in respect of their physical and chemical properties. Most often these are soils of urban and industrial type with a different degree of pollution and contamination (K u k i e r, 1985; T u r s ki et al. 1993). Highly productive soils of anthropogenic type predominate in the arable land widespread around the city's central part.

\section{METHODS}

The survey was carried out during the 20022008 growing seasons in Lublin city and its results were compared to historical literature data ( $\mathrm{K}$ a ro , 1883; K o porska, 1929; Fijałkowski, 1954, 1960, 1967; Święs and Wrzesién, 2002, 2003, 2004; B a 1 a n a et. al. 2006; R y s i a k, 2009; 2009a; R y siak, et al. 2008, 2008a). The floristic material comprised data obtained during the present field stu$\mathrm{dy}$, from literature searches, and data from herbarium collections. Observations of the entire flora were made during the peak growing season. Species belonging to the classes Festuco-Brometea, Trifolio-Geranietea sanguinei, Rhamno-Prunetea and lower syntaxa of these classes (M atu s zki ew ic z, 2008) as well as species which find the optimum of their distribution in xerothermic communities ( $\mathrm{Z}$ a r z y c k i et al. 2002) were regarded as xerothermic species.

Habitat conditions and scale of species hemeroby were evaluated during the field research. Special attention was paid to the land use in the area (Table 1.). Regarding the scope and intensity of anthropopressure, it is divided into 4 degrees of hemeroby ( $\mathrm{S} \mathrm{u} \mathrm{k} \mathrm{o} \mathrm{p} \mathrm{p,} \mathrm{1972).}$ The degree of hemeroby of a species was described on the basis of frequency of its occurrence and the value of RHI (Real Hemeroby Index) proposed by (J a c k o w i a k, 1998), according to the following formula:

$$
\begin{aligned}
\mathrm{RIH}= & (\text { eu }+ \text { poly species })-(\text { oli }+ \text { meso species }) \\
& / \boldsymbol{\Sigma} \text { species in the study area }
\end{aligned}
$$

Table 1

\begin{tabular}{|c|c|c|}
\hline Degree of hemeroby & Definition & Occurrence in the study area \\
\hline $\begin{array}{l}\text { oligohemerobic } \\
\text { [oli I] }\end{array}$ & $\begin{array}{l}\text { Little anthropogenic influence takes place, actual } \\
\text { vegetation corresponds with natural vegetation }\end{array}$ & $\begin{array}{l}\text { The best preserved patches of forests, meadows, } \\
\text { xerothermic grasslands and water biotopes. }\end{array}$ \\
\hline $\begin{array}{l}\text { mesohemerobic } \\
\text { [meso II] }\end{array}$ & $\begin{array}{l}\text { Anthropogenic factors take place in a low } \\
\text { to moderate degree. Semi-natural vegetation. }\end{array}$ & $\begin{array}{l}\text { Biotopes of utilized forests, bushes, meadows pas- } \\
\text { tures, grasslands, most of water and aquatic habitats }\end{array}$ \\
\hline $\begin{array}{l}\text { euhemerobic } \\
\text { [eu III] }\end{array}$ & $\begin{array}{l}\text { Anthropogenic factors act constantly } \\
\text { to a high degree. Ruderal and segetal plants, } \\
\text { transformed semi-natural communities. }\end{array}$ & $\begin{array}{l}\text { Field and garden habitats, fallow grounds, } \\
\text { flower-beds, waste lands. }\end{array}$ \\
\hline $\begin{array}{l}\text { polyhemerobic } \\
\text { [poly IV] }\end{array}$ & $\begin{array}{l}\text { Influence of anthropogenic factors is constant } \\
\text { and very strong. Vegetation has a high degree of } \\
\text { specialization and pioneer character. }\end{array}$ & $\begin{array}{l}\text { Inter-track spaces, railway areas, dumping sites } \\
\text { hardened with gravel squares and roadsides, } \\
\text { next to walls and slits in walls, sediment traps. }\end{array}$ \\
\hline
\end{tabular}

Scale of hemeroby by S u k op p (1972), changed

The species are listed in alphabetical order (Table 2) and their nomenclature follows $\mathrm{Mirek}$ et al. (2002). The description of each taxon includes its threat category after M i r e k et al. (2006) for Poland and after Kucharczyk (2003) for the Lublin region.
The categories of species protection are listed (Regulation... 2004). The affiliation of grassland species to individual ecological and geographical elements was determined according to $\mathrm{Zaj}$ ąc and $\mathrm{Zając}$ (1992) as well as Zają c and Tokarska-Guzik, 
(1998), while life forms according to Z a r z y c k i et al. (2002).

The distribution of species was recorded using a grid of $1 \mathrm{x} 1 \mathrm{~km}$ squares. These basic units were arranged in accordance with the ATPOL grid $(\mathrm{Z} \mathrm{a} \mathrm{j} \mathrm{a} \mathrm{c}$, 1978). The studied area covering the city of Lublin within its administrative boundaries consists of 4 "large" $10 \times 10 \mathrm{~km}$ squares of the ATPOL grid and $188 \mathrm{squ}-$ ares of $1 \times 1 \mathrm{~km} .117$ of them fit entirely in the area of Lublin and 66 are boundary squares (Fig. 1). The occurrence of a species in a square was regarded as its locality. To illustrate their frequencies of occurrence, the species were arranged in a series following frequency classes. Individual classes were identified relative to the total number of cartogram fields (Table 3).

\section{RESULTS}

107 xerothermic species belonging to 26 families and 70 genera were reported from the area of Lublin. The number constitutes $10 \%$ of the city's flora.
In turn, xerothermic species in other Polish cities constitute $5 \%$ in Warsaw (S u dnik - W ó j c i k ow ska, 1987), 7\% (69 species) in Poznań (J a ck owiak, 1998), 6\% in Łódź (Witosławski, 2006) and $12.5 \%$ in Bydgoszcz (K o r c z y ń s k i, 2010).

The class Festuco-Brometea is represented in Lublin by 70 species, whereas Rhamno-Prunetea and Trifolio-Geranietea sanguinei are represented by 16 and 21 species, respectively. The field study did not verify the localities of 8 species. The alphabetical list of the xerothermic flora, including data sources and information about the threat and protection category, are included in Table 2. The analysis of the spectrum of life forms indicates that the groups of hemicryptophytes (57 species) and phanerophytes (14 species) have the largest share in the flora of Lublin, while among the historical-geographical groups, native species (103) are predominant over antropophytes (4 species). The most interesting group of xerothermic plants comprises 21 species, including 6 legally protected and 15 endangered species at the regional and national level.

Table 2.

Alphabetical list of xerothermic species of vascular plants in Lublin, Poland

\begin{tabular}{|c|c|c|c|c|c|c|c|c|c|c|c|}
\hline $\mathbf{A}$ & $\mathbf{B}$ & & & $\mathbf{D}$ & & & $\%)$ & & $\mathbf{F}$ & $\mathbf{G}$ & $\mathbf{H}$ \\
\hline & Cl. FESTUCO-BROMETEA & $\mathbf{P}$ & $\mathbf{H}$ & & I & II & III & IV & & & \\
\hline 1 & Achillea pannonica & + & . & + & 28.6 & 50 & 14.3 & 7.1 & . & $\mathrm{V}$ & $\mathrm{V}$ \\
\hline 2 & Acinos arvensis & + & . & + & 22.6 & 0 & 16.1 & 48.4 & I & & \\
\hline 3 & Adonis vernalis & + & . & + & 100 & 0 & 0 & 0 & I & $\mathrm{V}$ & $\mathrm{V}, \mathrm{TP}$ \\
\hline 4 & Agrimonia eupatoria & + & . & + & 22.2 & 13.1 & 26.3 & 38.4 & III & & \\
\hline 5 & Ajuga genevensis & . & . & + & 22.7 & 59.1 & 4,5 & 13.6 & II & CR & CR \\
\hline 6 & Allium oleraceum & . & . & + & 44.8 & 17.2 & 20.7 & 17.2 & . & & \\
\hline 7 & Anthemis tinctoria & + & . & + & 12.5 & 0 & 50 & 37.5 & I & & \\
\hline 8 & Anthyllis vulneraria & + & . & + & 2.6 & 3.2 & 19.4 & 54.8 & I, IV & & \\
\hline 9 & Arabis hirsuta & + & . & + & 33.3 & 0 & 25 & 41.7 & I & & \\
\hline 10 & Artemisia campestris & + & . & + & 22.2 & 15.6 & 17.8 & 44.4 & I & & \\
\hline 11 & Asparagus officinalis & + & . & + & 20 & 21.2 & 29.4 & 29.4 & I & & \\
\hline 12 & Astragalus danicus & + & . & . & . & . & . & . & I & EN & \\
\hline 13 & Brachypodium pinnatum & + & . & + & 45 & 20 & 5 & 30 & I, II & & \\
\hline 14 & Bromus inermis & + & . & + & 17.3 & 15.4 & 32.7 & 34.6 & I, II, III & & \\
\hline 15 & Campanula glomerata & . & . & + & 66.7 & 0 & 16.7 & 16.7 & . & & \\
\hline 16 & C. sibirica & + & . & + & 50 & 31.8 & 9.1 & 9.1 & I & & $\mathrm{TP}$ \\
\hline 17 & Carex caryophyllea & . & . & + & 66.7 & 8.3 & 0 & 25 & . & & \\
\hline 18 & C. michelii & + & . & + & 100 & 0 & 0 & 0 & . & & \\
\hline 19 & C. praecox & + & . & + & 0 & 0 & 58.3 & 41.7 & I & & $\mathrm{V}$ \\
\hline 20 & Carlina vulgaris & . & . & + & 50 & 50 & 0 & 0 & . & & \\
\hline 21 & Centaurea scabiosa & + & . & + & 7.9 & 36.8 & 18,4 & 36.8 & . & & \\
\hline 22 & C. stoebe & . & . & + & 14 & 26 & 12 & 48 & . & & \\
\hline 23 & Cerastium pumilum & + & . & + & 0 & 0 & 100 & 0 & I & & V \\
\hline 24 & Cirsium acaule & . & . & + & 0 & 100 & 0 & 0 & . & & \\
\hline
\end{tabular}




\begin{tabular}{|c|c|c|c|c|c|c|c|c|c|c|c|}
\hline 25 & Crepis praemorsa & + & . & . & . & . & . & . & I, II & $\mathrm{V}$ & \\
\hline 26 & Dianthus carthusianorum & . & . & + & 57.9 & 36.8 & 0 & 5.3 & I, II & & \\
\hline 27 & Elymus hispidus & + & . & + & 14.3 & 42.9 & 0 & 42.9 & I, IV & & LR \\
\hline 28 & Erigeron acris & + & . & + & 17,1 & 18.6 & 38.6 & 25.7 & III, IV & & \\
\hline 29 & Euphorbia cyparissias & + & . & + & 23.9 & 22.2 & 22.2 & 31.6 & II, III & & \\
\hline 30 & Festuca rupicola & . & . & + & 11.1 & 11.1 & 22.2 & 55.6 & I & & EN \\
\hline 31 & F. trachyphylla & + & . & + & 20 & 20 & 40 & 20 & I & & \\
\hline 32 & F. valesiaca & . & . & + & 100 & 0 & 0 & 0 & . & & \\
\hline 33 & Filipendula vulgaris & + & . & + & 40.9 & 36.4 & 18.2 & 4.5 & . & & \\
\hline 34 & Galium album & . & . & + & 0 & 0 & 100 & 0 & . & & \\
\hline 35 & Helianthemum nummularium & + & . & + & 0 & 100 & 0 & 0 & . & & \\
\hline 36 & Hieracium bauhinii & + & . & + & 27.1 & 18.6 & 20.3 & 33.9 & . & & \\
\hline 37 & Jovibarba sobolifera & . & . & + & 100 & 0 & 0 & 0 & . & & EN, TP \\
\hline 38 & Koeleria glauca & . & . & + & 100 & 0 & 0 & 0 & . & & \\
\hline 39 & K. macrantha & . & . & + & 25 & 37.5 & 0 & 37.5 & II & $\mathrm{V}$ & $\mathrm{V}$ \\
\hline 40 & Linum flavum & + & . & . & & & & & . & $\mathrm{E}$ & \\
\hline 41 & Myosotis ramosissima & . & . & + & 29.4 & 23.5 & 41.2 & 5.9 & I & V & $\mathrm{V}$ \\
\hline 42 & Onobrychis viciifolia & . & . & + & 100 & 0 & 0 & 0 & . & & \\
\hline 43 & Orobanche lutea & + & . & + & 100 & 0 & 0 & 0 & III & & ТP \\
\hline 44 & Phleum phleoides & + & . & + & 100 & 0 & 0 & 0 & . & & LR \\
\hline 45 & Plantago media & + & . & + & 27.9 & 13.2 & 27.9 & 30.9 & II, III & & \\
\hline 46 & Poa bulbosa & . & . & + & 0 & 100 & 0 & 0 & . & DD & \\
\hline 47 & P. compressa & . & . & + & 18.8 & 13.4 & 28.9 & 38.9 & . & & \\
\hline 48 & Polygala comosa & + & . & + & 42.9 & 28.6 & 0 & 28.6 & . & & \\
\hline 49 & Potentilla arenaria & + & . & + & 28 & 32 & 22 & 18 & I, II, III & & \\
\hline 50 & P. heptaphylla & + & . & + & 20 & 20 & 0 & 60 & I, II & & \\
\hline 51 & P. recta & + & . & + & 14.3 & 19 & 28.6 & 38.1 & . & & \\
\hline 52 & Ranunculus bulbosus & + & . & + & 25 & 26.4 & 15.3 & 33.3 & . & & \\
\hline 53 & Salvia nemorosa & . & . & + & 0 & 100 & 0 & 0 & IV & $\mathrm{EN}$ & \\
\hline 54 & S. pratensis & + & . & + & 38.6 & 25 & 15.9 & 20.5 & I & & \\
\hline 55 & S. verticillata & + & . & + & 23.3 & 23.3 & 2.9 & 50.5 & I & & \\
\hline 56 & Scabiosa ochroleuca & + & . & + & 54.2 & 8.3 & 20.8 & 16.7 & I & & \\
\hline 57 & Scorzonera purpurea & + & + & . & . & . & . & . & . & $\mathrm{EN}$ & $\mathrm{R}$ \\
\hline 58 & Seseli annuum & + & . & + & 0 & 50 & 0 & 50 & III & & \\
\hline 59 & Silene dichotoma & + & . & . & . & . & . & . & II & & \\
\hline 60 & Stachys germanica & . & + & . & . & . & . & . & I, II & & \\
\hline 61 & S. recta & + & . & + & 37.5 & 43.8 & 9.4 & 9.4 & I & & \\
\hline 62 & Teucrium chamaedrys & + & . & + & 100 & 0 & 0 & 0 & I & $\mathrm{C}$ & $\mathrm{V}$ \\
\hline 63 & Thalictrum minus & + & . & + & 45.7 & 23.9 & 8.7 & 21.7 & I & $\mathrm{V}$ & $\mathrm{V}$ \\
\hline 64 & T. simplex & . & . & + & 100 & 0 & 0 & 0 & . & $\mathrm{V}$ & $\mathrm{V}$ \\
\hline 65 & Thesium linophyllum & + & + & . & . & . & . & . & I, III & $\mathrm{V}$ & \\
\hline 66 & Verbascum phoeniceum & . & . & + & 50 & 27.8 & 16.7 & 5.6 & . & & \\
\hline 67 & Veronica austriaca & . & . & + & 44.4 & 11.1 & 44.4 & 0 & I, II & $\mathrm{V}$ & $\mathrm{V}$ \\
\hline 68 & V. spicata & + & . & + & 48.1 & 18.5 & 14.8 & 18.5 & I & & \\
\hline 69 & Vincetoxicum hirundinaria & + & . & + & 29 & 29 & 6.5 & 35.5 & . & & \\
\hline 70 & Viola rupestris & + & + & . & . & . & . & . & I & & \\
\hline \multicolumn{12}{|c|}{ CL. RHAMNO-PRUNETEA } \\
\hline 71 & Berberis vulgaris & . & . & . & 32.1 & 25 & 14.3 & 28.6 & . & & \\
\hline 72 & Cerasus fruticosa & + & . & + & 79.3 & 17.2 & 0 & 34 & I, II & $\mathrm{CR}$ & $\mathrm{V}, \mathrm{TP}$ \\
\hline 73 & Clematis vitalba & + & . & + & 6.1 & 18.2 & 45.5 & 30.3 & III & & \\
\hline
\end{tabular}




\begin{tabular}{|c|c|c|c|c|c|c|c|c|c|c|}
\hline 74 & Cornus sanguinea & . & . & + & 27.8 & 15.2 & 27.8 & 29.1 & . & \\
\hline 75 & Cotoneaster integerrimus & . & . & + & 0 & 0 & 50 & 50 & . & \\
\hline 76 & Crataegus leavigata & . & . & + & 66.7 & 33.3 & 0 & 0 & . & \\
\hline 77 & C. monogyna & . & . & + & 27 & 16.2 & 27 & 29.7 & . & \\
\hline 78 & C. riphidophylla & . & . & + & 0 & 100 & 0 & 0 & . & \\
\hline 79 & Prunus spinosa & . & . & + & 16.1 & 30.6 & 17.7 & 35.5 & . & \\
\hline 80 & Rhamnus catharticus & + & . & + & 23.1 & 53.8 & 0 & 23.1 & . & \\
\hline 81 & Rosa canina & + & . & + & 31.6 & 18.4 & 21.1 & 28.9 & . & \\
\hline 82 & R. dumalis & . & . & + & 33.3 & 27.8 & 27.8 & 11.1 & . & \\
\hline 83 & R. glauca & . & . & + & 0 & 0 & 100 & 0 & . & \\
\hline 84 & R. rubiginosa & + & . & + & 0 & 100 & 0 & 0 & . & \\
\hline 85 & R. spinosissima & + & . & + & 100 & 0 & 0 & 0 & . & \\
\hline 86 & R. tomentosa & . & . & + & 0 & 50 & 0 & 50 & . & $\mathrm{V}$ \\
\hline \multicolumn{11}{|c|}{ CL. TRIFOLIO-GERANIETEA SANGUINEI } \\
\hline 87 & Anemone sylvestris & . & . & + & 40 & 40 & 20 & 0 & I & $\mathrm{TP}$ \\
\hline 88 & Anthericum ramosum & + & . & + & 60 & 0 & 20 & 20 & . & \\
\hline 89 & Astragalus cicer & + & . & + & 10.6 & 13.6 & 36.4 & 39.4 & I, IV & \\
\hline 90 & A. glycyphyllos & + & . & + & 14.9 & 17.9 & 32.8 & 34.3 & . & \\
\hline 91 & Campanula bononiensis & + & . & + & 69.2 & 7.7 & 0 & 23.1 & . & $\mathrm{TP}$ \\
\hline 92 & C. rapunculoides & . & . & + & 27 & 19.1 & 27.8 & 26.1 & . & \\
\hline 93 & Clematis recta & . & . & + & 0 & 50 & 25 & 25 & . & \\
\hline 94 & Clinopodium vulgare & . & . & + & 41.7 & 23.3 & 10 & 25 & . & \\
\hline 95 & Coronilla varia & . & . & + & 14.5 & 24.2 & 22.6 & 38.7 & . & \\
\hline 96 & Fragaria viridis & . & . & + & 100 & 0 & 0 & 0 & I & \\
\hline 97 & Galium verum & + & . & + & 19 & 15.5 & 32.1 & 33.3 & I, III & \\
\hline 98 & Geranium sanguineum & . & . & + & 50 & 15 & 20 & 15 & III & \\
\hline 99 & Lathyrus sylvestris & + & . & + & 47.8 & 8.7 & 8.7 & 34.8 & . & \\
\hline 100 & Medicago falcata & . & . & + & 25.3 & 14.1 & 26.3 & 34.3 & . & \\
\hline 101 & Origanum vulgare & + & . & + & 38.3 & 8.3 & 15 & 38.3 & I, III & \\
\hline 102 & Silene nutans & + & . & + & 50 & 50 & 0 & 0 & . & \\
\hline 103 & Trifolium alpestre & . & . & + & 45.5 & 18.2 & 18.2 & 18.2 & . & \\
\hline 104 & T. medium & + & . & + & 25.3 & 14.3 & 29.7 & 30.8 & . & \\
\hline 105 & Veronica teucrium & + & . & + & 71.4 & 28.6 & 0 & 0 & . & \\
\hline 106 & Vicia tenuifolia & . & . & + & 0 & 0 & 42.9 & 57.1 & . & \\
\hline 107 & Viola hirta & . & . & + & 100 & 0 & 0 & 0 & . & \\
\hline
\end{tabular}

Explanations: A - number; $\mathbf{B}$ - species; $\mathbf{C}$ - historical data $(\mathbf{P}$ - papers, $\mathbf{H}$ - herbarium); $\mathbf{D}$ - current data; $\mathbf{E}$ - percentage share according to the degree of habitat hemeroby for the recorded flora (for abbreviations see Tab. 1), $\mathbf{F}-$ degree of hemeroby in historical records (for abbreviations see Tab. 1); G - local "Red list"; H - national "Red List" and legal protection of species: EN- endangered species, CR - critically endangered species, DD - data deficient species, LR - lower risk species, TP - total legal protection, V - vulnerable species.

Xerothermic plants exhibit a mosaic distribution in the area of Lublin. They occur in nearly all the study units, although with varied density (Figs 2-4). The highest share within the city area was recorded for the representatives of the class Festuco-Brometea, which were noted in 154 study units covering $82 \%$ of the study area. Large concentrations of representatives of this class comprising 13-30 species were recorded in as many as 34 squares, while in the other squares there were from 1 to 6 species. Plants from the classes Rhamno-Prunetea and Trifolio-Geranietea sanguinei were found in $112(60 \%)$ and $135(72 \%)$ study units, respectively. The lowest quantitative and qualitative proportion in the xerothermic flora of Lublin was observed among the species in the Rhamno-Prunetea class. They did not form dense clusters and only 5-6 species were found in 4 study units. Compared to the aforementioned plants, the representatives of the class Trifolio-Geranietea sanguinei exhibited a medium quantitative and qualitative proportion. Their localities containing 9-12 species were only recorded in 15 ATPOL squares. 


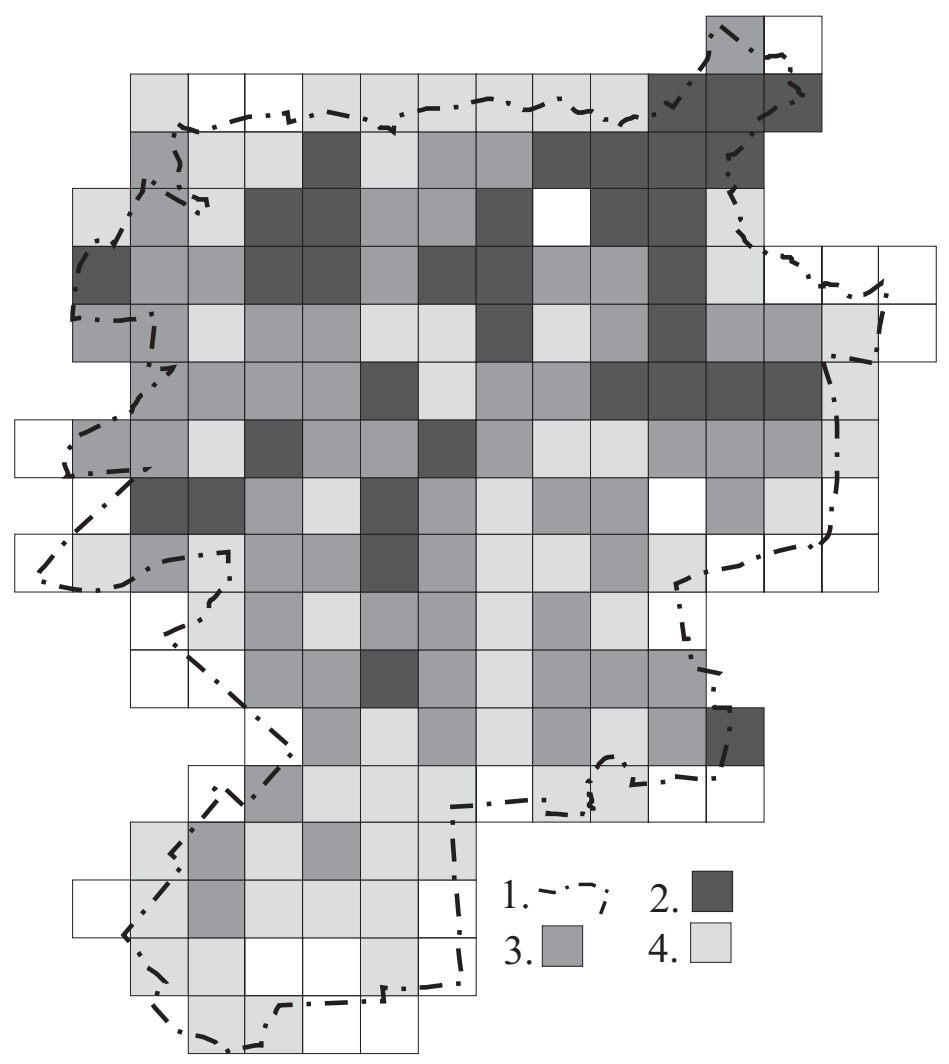

Fig. 2. Distribution of the species from the Festuco-Brometea class within the area of Lublin, Poland: $1-$ city limits; $2-13-30$ species in the square; $3-6-12$ species in the square; $4-1-5$ species in the square.

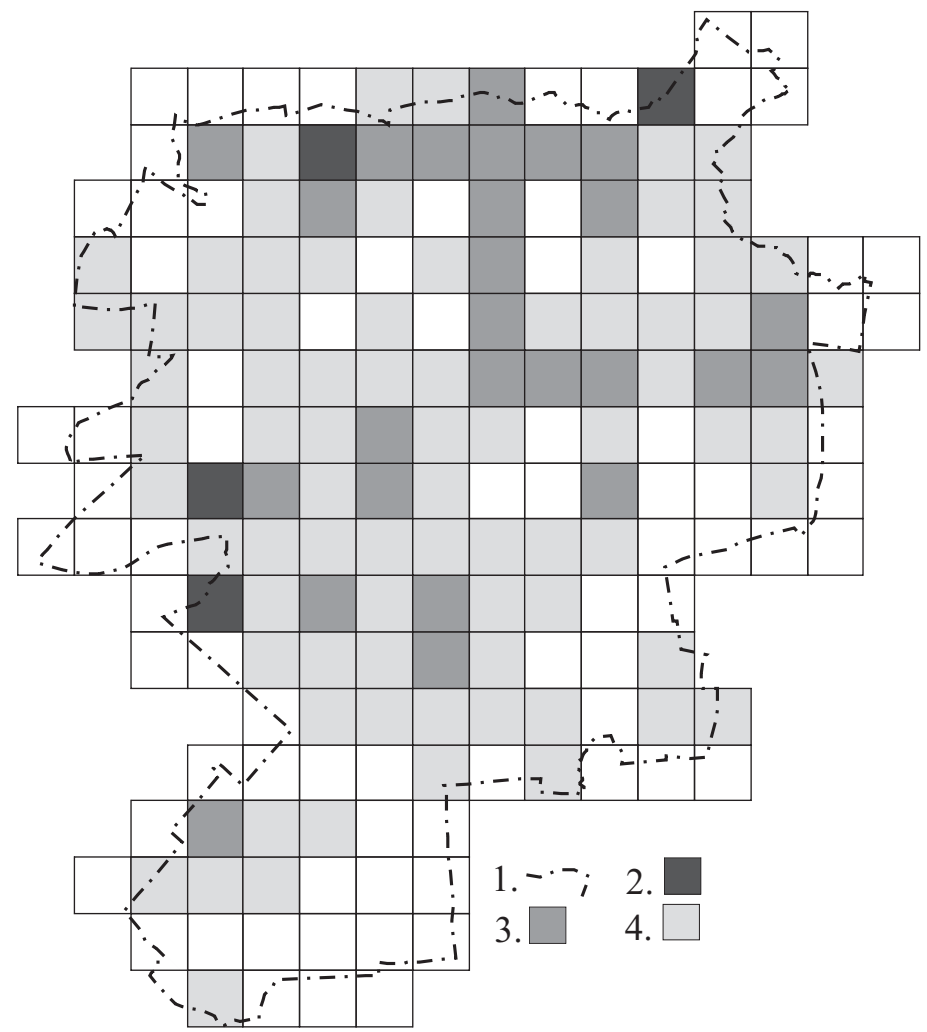

Fig. 3. Distribution of species from the Rhamno-Prunetea class within the area of Lublin, Poland: 1 - city limits; $2-5-6$ species in the square; $3-3-4$ species in the square; $4-1-2$ species in the square. 


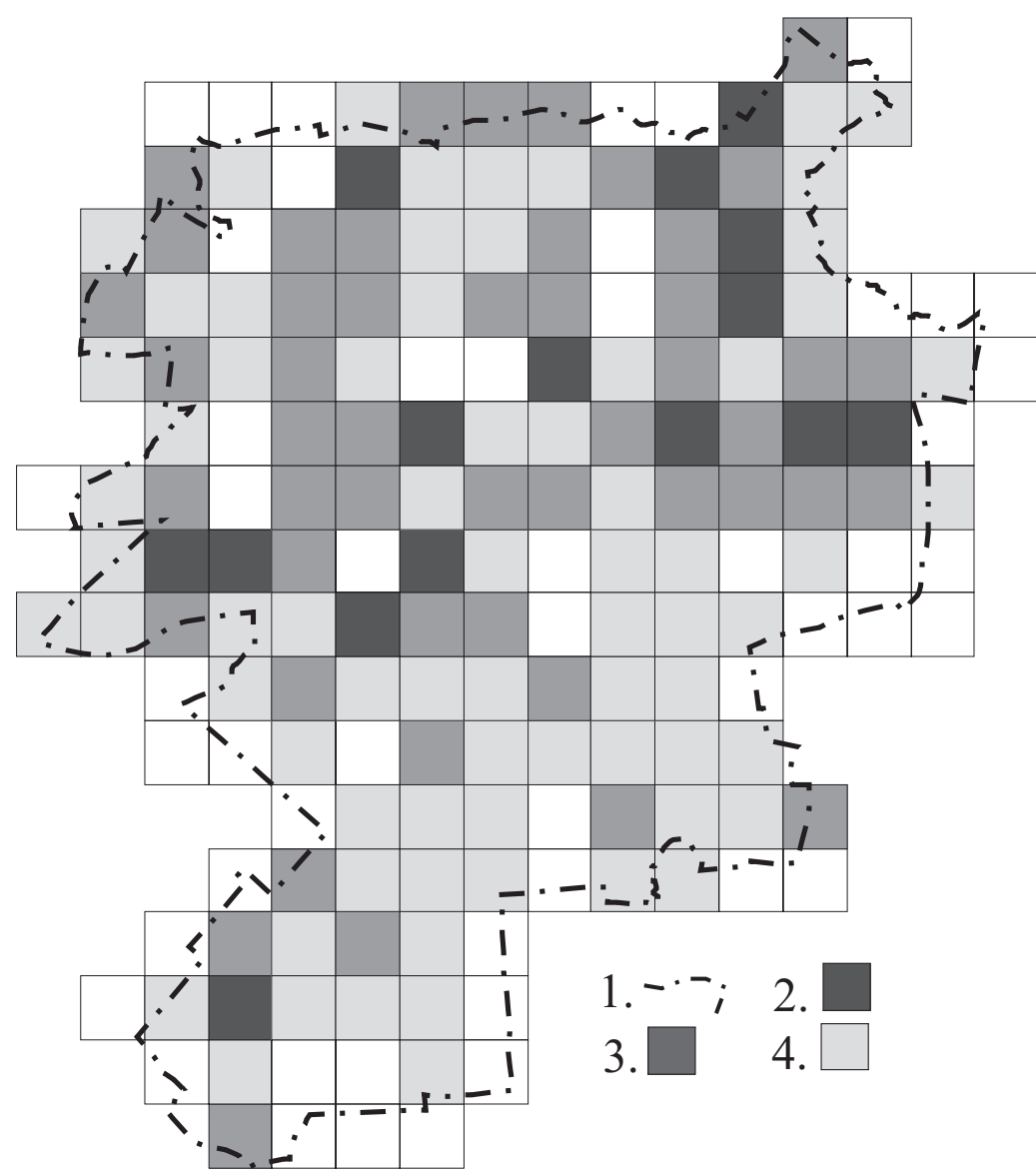

Fig. 4. Distribution of species from the Trifolio-Geranietea sanguinei class within the area of Lublin, Poland: 1 - city limits; 2 9-12 species in the square; $3-5-8$ species in the square; $4-1-4$ species in the square.

The frequency (measured as the presence of a species in a study unit, one ATPOL square) ranged from 1 to 44 species within the study area. The proportion of squares with the presence of the analyzed species varied among the different habitats in the Lublin area. Two main features of the analyzed area seemed to be responsible for species distribution: the value of the Real Hemeroby Index (RIH) and the history of the flora. Grassland species were much more abundant in the NE and $\mathrm{N}$ districts of the Lublin city area. They are concentrated mainly in places close to sources of propagules, which are located in the patches of grasslands characterised in the historical papers. The main factor which slows down the pro- cess of colonization and distribution in the studied area is the increasing Real Hemeroby Index (RIH) (Fig. 5). The value of RIH in Lublin on the ATPOL grid varied between 0.11 and 0.48 . Xerothermic species were less frequent in the squares with maximum values of RIH.

A large group of xerothermic species (more than $60 \%$ ) at present consists of very rare and rare species in the Lublin city area (Table 3). As few as 6 species can be regarded as wide-spread and very common. These are: Verbascum phlomoides (185 localities), Bromus inermis (172), Plantago media (141), Medicago falcata (139) Coronilla varia (122), and Asparagus officinalis (98 localities). 


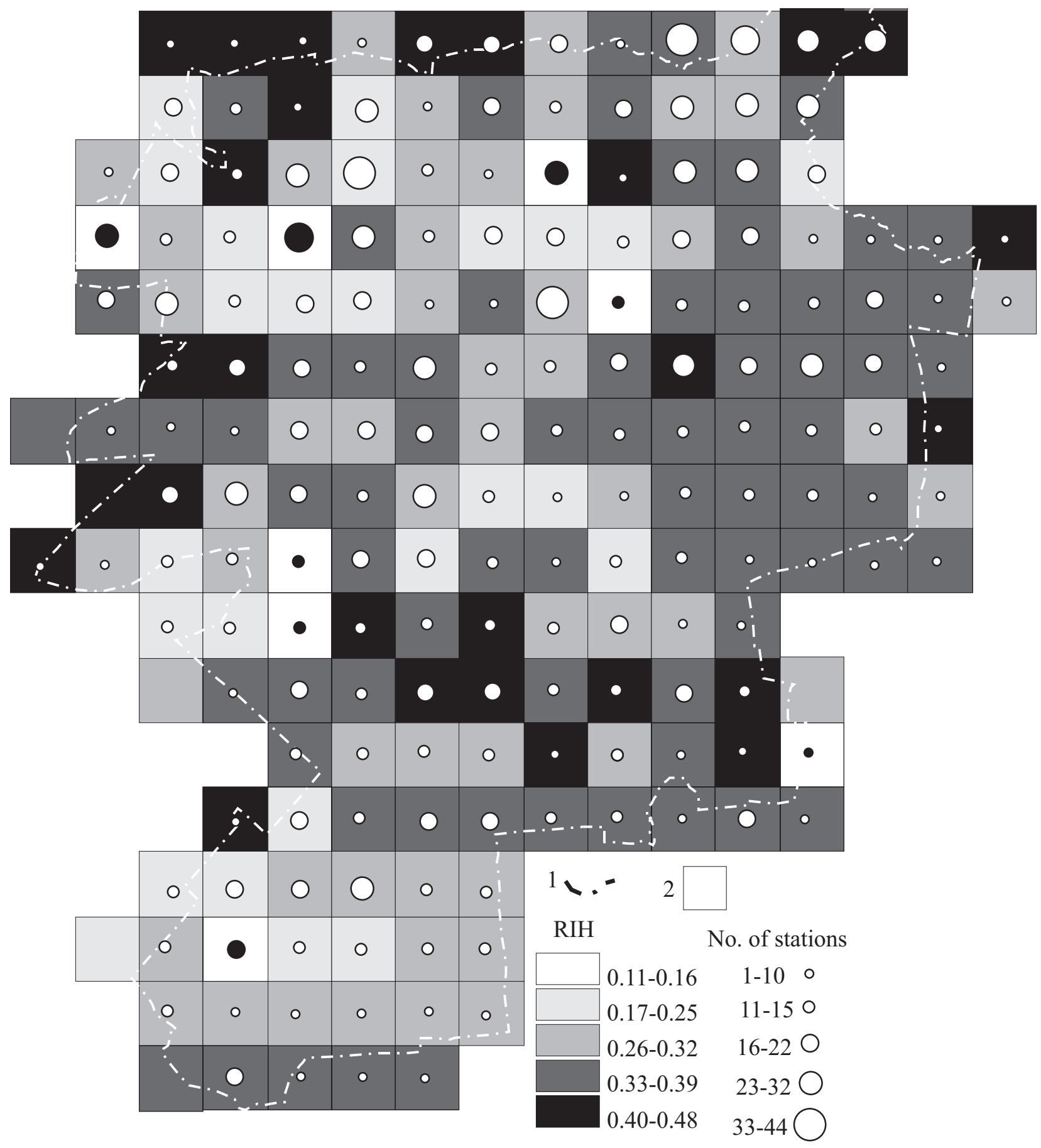

Fig. 5. Distribution of xerothermic species in the area of Lublin on the ATPOL grid square and RIH values: 1 -city limits; 2 - ATPOL grid square $(1 \mathrm{~km} \times 1 \mathrm{~km})$.

In some cases, anthropogenic habitats are the important sites of those species. For example, Carex praecox, Campanula sibirica, C. bononiensis, Elymus hispidus, Festuca rupicola and other (Fig. 6) occurred in olygo- and meso- and polyhemerobic habitats.
For some other species, anthropogenic habitats have a significant share in habitat spectrum, e.g. Agrimonia eupatoria, Anthemis tinctoria, Arenaria serpyllifolia, Arabis hirsuta, Astragalus cicer (Fig. 7). 


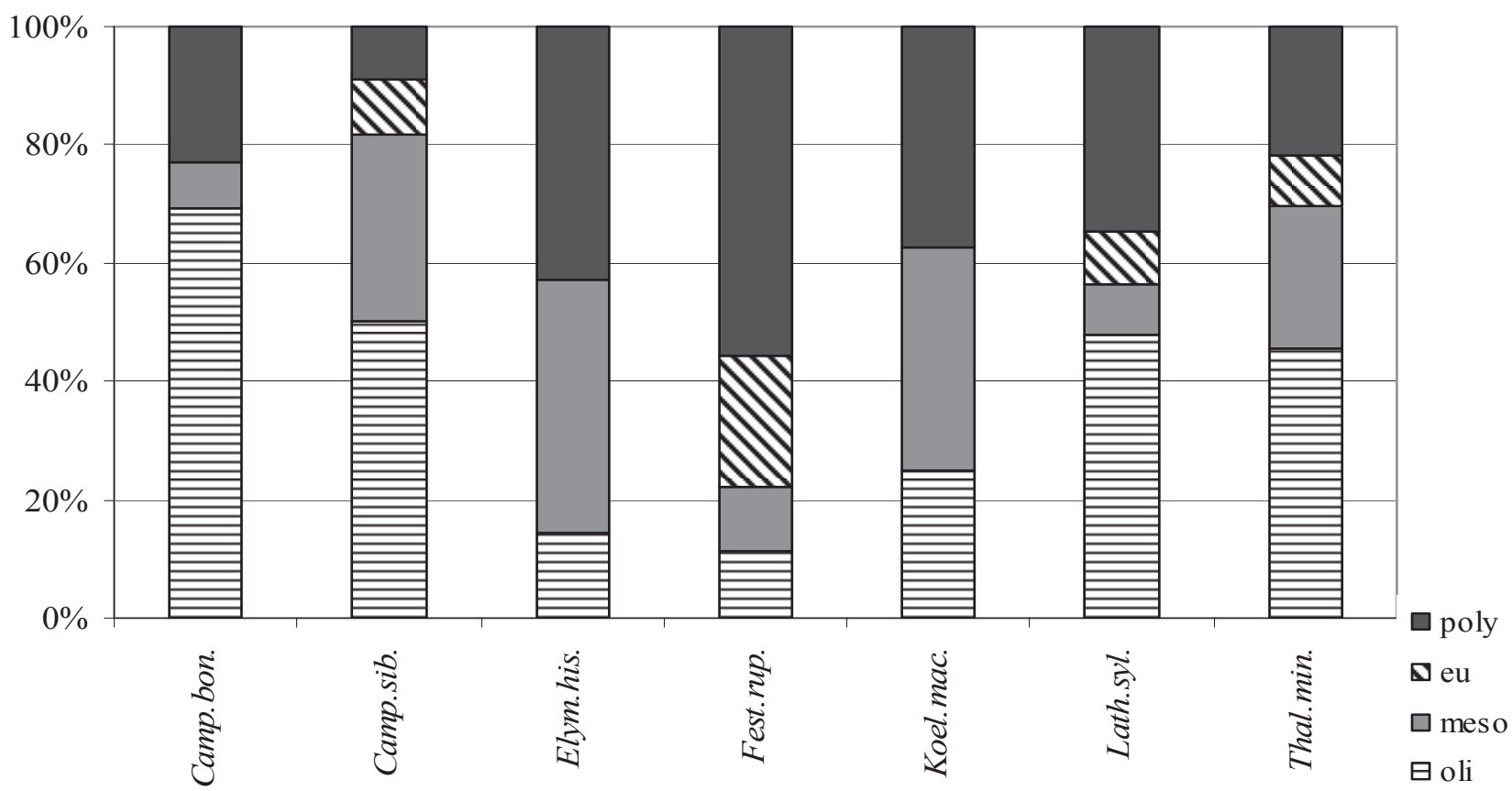

Fig. 6. Share of protected xerothermic species in habitats of different degrees of hemeroby (for explanation of abbreviations see Table 1). Camp.bon.-Campanula bononiensis, Camp.sib.-Campanula sibirica, Elym.his.-Elymus hispidus, Fest.rup.Festuca rupicola, Koel.mac.-Koeleria macrantha, Lath.syl.-Lathyrus sylvestris, Thal.min.-Thalictrum minus.

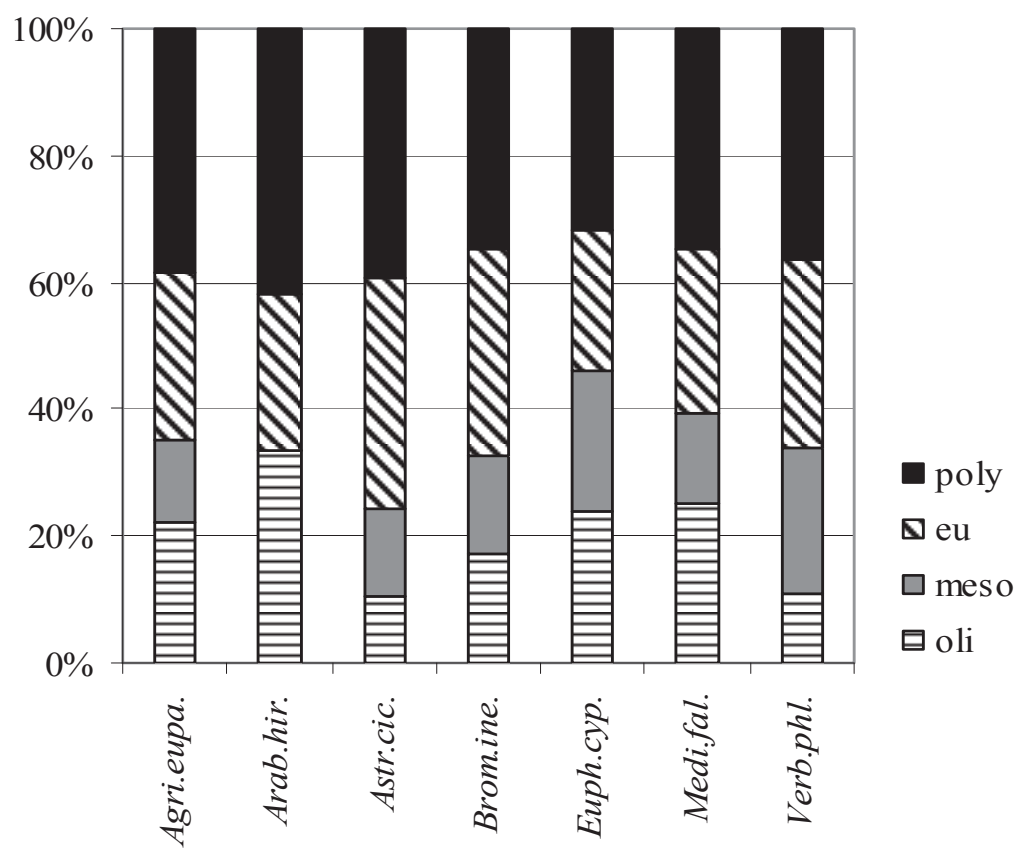

Fig. 7. Share of common xerothermic species in habitats of different degrees of hemeroby (for explanation of abbreviations see Table 1). Agri.eupa.-Agrimonia eupatoria, Arab.hir.-Arabis hirsuta, Astr.cic.-Astragalus cicer, Brom.ine.-Bormus inermis, Euph.cyp.-Euphorbia cyparisias, Medi.fal.-Medicago falcata, Verb.pho.-Verbascyum phoeniceum. 
Table 3

Frequency of xerothermic plant species occurring in the area of Lublin city

\begin{tabular}{|c|c|c|c|c|c|}
\hline Frequency & Frequency class & $\%$ of cartogram fields & No. of localities & No. of species & Share $(\%)$ \\
\hline Not found (extinct) & - & 0 & 0 & 8 & 7.6 \\
\hline Very rare & I & $0.1-4.0$ & $1-7$ & 29 & 27.6 \\
\hline Rare & II & $4.1-12.0$ & $8-22$ & 36 & 34.3 \\
\hline Frequent & III & $12.1-25.0$ & $23-47$ & 13 & 12.4 \\
\hline Common & IV & $25.1-50.0$ & $48-94$ & 13 & 12.4 \\
\hline Very common & $\mathrm{V}$ & $50.1-75.0$ & $95-140$ & 3 & 2.8 \\
\hline Abundant & VI & $75.1-100.0$ & $141-188$ & 3 & 2.8 \\
\hline
\end{tabular}

\section{DISCUSSION}

The uneven distribution of the xerothermic species reported for the particular phytosociological classes may have a diverse background. Grassland species with a broader ecological spectrum spread from the "centres" of their occurrence in the city towards anthropogenic substitute habitats: railways, road edges and embankments, loess slopes, and lawns. The most interesting patches of xerothermic vegetation within Lublin are located in Rudnik, where they were already described in the 50's of the $20^{\text {th }}$ century (F i j a $1 \mathrm{k} \mathrm{ow}$ ski, 1954; Izdebski, 1957; Fijałkowski and I z d e b s k i , 1957), as well as in Lipnik (B a l a n a et al. 2006) and in "Górki Czechowskie" (B a l a n a et al. 2004). The shrub vegetation in the Lublin area is merely the remnant of midfield shelterbelts or fringe communities. Its insignificant share in the Lublin flora results from the lack of suitable habitats, which have been converted into cultivation areas or arranged greenery.

In comparison to the historical data, the xerothermic flora of Lublin has lost 8 valuable species and the share of the other species has declined substantially. The causes of disappearance of xerothermic vegetation in the Lubelszczyzna region include large-scale mechanized farming, afforestation, and natural succession of trees (Fijałk ow ski, 1988). Within the city boundaries, the causes include the increasing use of land for housing development, recreation, and transportation.

\section{Acknowledgements}

I would like to thank unknown reviewers for valuable remarks on this manuscript.

\section{REFERENCES}

Balana M., Czaraniawski W., Czepiec K., Gosik R., Ptaszyńska A., 2004. Walory przyrodnicze projektowanego rezerwatu Górki Czechowskie w Lublinie - stan aktualny i perspektywy rozwoju.
/ The natural values of the proposed Górki Czechowskie nature reserve in the city of Lublin - the present status and prospects for its development. Chroń. Przyr. Ojcz. 60 (1): 67-77. (in Polish)

Balana M., Buczyński P., Czerniawski W., Dembicka A., Grądziel T., Ptaszyńska A., Stączek Z., 2006. Uroczysko Lipnik - cenny przyrodniczo wąwóz lessowy w Lublinie. / "Uroczysko Lipnik" - an environmentally valuable loess gully in Lublin. Chroń. Przyr. Ojcz. 62, 1:42-51. (in Polish)

Chałubińska A., Wilgat T., 1954. Podział fizjograficzny województwa lubelskiego. [In]: Przewodnik V Ogólnopolskiego Zjazdu PTG. Lublin pp: 3-44. (in Polish)

Denisow B., Wrzesień M., Cwener A., 2008. The estimation of Adonis vernalis populations in chosen patches of Lublin Upland. Acta Agrobot. 61 (1): 3-11.

Fij a ł k ow sk i D., 1954. Szata roślinna wąwozów okolic Lublina na tle niektórych warunków siedliskowych. / The vegetation cover of the ravines in the area of Lublin relative to some habitat conditions. Ann. UMCS sect. C. 9: 125-215. (in Polish)

Fijałkowski D., 1960. Wykaz rzadszych roślin Lubelszczyzny. Część 4. Fragm. Florist. Geobot. 6(3): 261-286. (in Polish)

Fijałkowski D., 1967. Zbiorowiska roślin synantropijnych miasta Lublina. / Communities of synanthropic plants of the city of Lublin. Ann. UMCS sect. C. 22: 195-233. (in Polish)

Fijałkowski D., Izdebski K., 1957. Zbiorowiska stepowe Wyżyny Lubelskiej. / Steppe plant associations of the Lublin Upland. Ann. UMCS, sect. B. 11: 167-199. (in Polish).

Harasimiuk M., Henkiel A., 1982. Objaśnienia do szczegółowej mapy geologicznej Polski, Arkusz Lublin (749) 1: 50 000. Wyd. Geol, Warszawa: 83. (in Polish)

I zdebski K., 1957. Zbiorowiska z roślinnością kserotermiczną w Rudniku k. Lublina i Dobużku k. Łaszczowa. / Xerothermic plant associations in Rudnik near Lublin and Dobużek near Łaszczów. Acta Soc. Bot. Poloniae, 27 (4): 631-648. (in Polish)

Jackowiak B., 1990. Anthropogenic changes of the flora of vascular plants of Poznań. Seria Biologia 42. Wyd. 
Nauk. Uniwersytetu im. Adama Mickiewicza, Poznań.

Ja ck owiak B ., 1998. Struktura przestrzenna flory dużego miasta. Studium metodyczno-problemowe. / The spatial structure of urban flora. A methodical-cognitive study. Prace Zakładu Taksonomii Roślin UAM w Poznaniu, 8: 1-227. Bogucki Wyd. Nauk., Poznań. (in Polish)

K a r o F., 1883. Spis rzadszych roślin zebranych w latach 1881 i 1882 w okolicach Lublina oraz pod Stawską Górą za Chełmem. Pamięt. Fizyogr. 3: 292-315. Warszawa. (in Polish)

Kaszewski B. M., Mrugała S., Warakomski W., 1995. Klimat. 1. Temperatura powietrza i opady atmosferyczne na obszarze Lubelszczyzny 1951-1990. [In]: Środowisko przyrodnicze Lubelszczyzny. LTN, Lublin, pp: 1-74. (in Polish)

Kondracki J., 2009. Geografia fizyczna Polski. Wydawnictwo Naukowe PWN, Warszawa. (in Polish)

Koporska H., 1929. Spis roślin rzadziej spotykanych w okolicach Lublina i niektórych innych miejscowościach województwa lubelskiego. Acta Soc. Bot. Poloniae 6(4): 350-366. (in Polish)

K o r c zy ń ski M., 2010. Udział gatunków kserotermicznych we florze Bydgoszczy. The xerothermic species share in the Bydgoszcz flora. [In]: Ciepłolubne murawy w Polsce-stan zachowania i perspektywy ochrony. H. Ratyńska, B. Waldon (eds), Wyd. Uniwersytetu Kazimierza Wielkiego, Bydgoszcz: 208-216. (in Polish)

Kucharczyk M., 2003. Lista ginących i zagrożonych gatunków roślin naczyniowych województwa lubelskiego. Wersja 3. 2. 1-9. (mns.). (in Polish)

Kukier U., 1985. Stan zanieczyszczenia metalami ciężkimi wierzchniej warstwy gleb Lublina / Status of poluttion by heavy metals topcoat soil of Lublin. Ann. UMCS sect. B, 40: 219-228. (in Polish)

Maruszczak H., 1958. Charakterystyczne formy rzeźby obszarów lessowych Wyżyny Lubelskiej. Czas. Geogr. 29: 335-353. (in Polish)

Matuszkiewicz W., 2008. Przewodnik do oznaczania zbiorowisk roślinnych Polski. Guide for identification of plant communities in Poland. Vademecum Geobotanicum, 3. Wydawnictwo Naukowe PWN, Warszawa. (in Polish)

Mirek Z., Piękoś-Mirkowa H., Zając A., Zając M., 2002. Flowering Plants and Pteridiophytes of Poland. Checklist. W. Szafer Institute of Botany, Polish Academy of Sciences, Kraków.

Rozporządzenie Ministra Środowiska z dnia 9 lipca 2004 r. w sprawie gatunków dziko występujących roślin objętych ochroną. Regulation of the Minister of Environment of 9 July 2004 on protected wild plants. (Dz. U. $\mathrm{Nr}$ 168, poz.1764).

Mirek Z., Zarzycki K., Wojewoda W., Szeląg Z., 2006. Red list of plants and fungi in Poland. W. Szafer Institute of Botany, Polish Academy of Sciences, Kraków.
Rysiak A., 2009. Flora roślin naczyniowych Lublina i jej antropogeniczne przemiany. Zakład Geobotaniki, Uniwersytet Marii Curie-Skłodowskiej w Lublinie, Lublin, manuscript of Pf. D. Thesis. (in Polish)

Rysiak A., 2009a. Extinct species in the vascular plant flora of Lublin city (E Poland). [In:] Rare, relict and endangered plants and fungi in Poland. Z. Mirek, A. Nikel (eds.) W. Szafer Insitute of Botany, Polish Academy of Sciences, Kraków: 443-455.

Rysiak A., Święs F., Świniarski P., 2008. Floristic sights of Lublin City. Ann. UMCS sect. C. 63: 7-24.

Rysiak A., Święs F., Świniarski P., 2008a. Rzadsze rośliny naczyniowe $\mathrm{z}$ obszaru Lublina. / Rare synanthropic vascular plants in the area of Lublin. Ann. UMCS sect. E. 63: 34-54. (in Polish)

St ochlak J., (ed). 1999. Raport o stanie środowiska miasta Lublina. Miejski Inspektorat Ochrony Środowiska Urzędu Miejskiego w Lublinie. (in Polish)

Sudnik-Wójcikowska B ., 1987. Flora miasta Warszawy i jej przemiany w ciągu XIX i XX w. Cz 1 i 2. Wydawnictwo UW, Warszawa. (in Polish)

S uk op p H., 1972. Wandel von flora und Vegetation in Mitteleuropa unter dem Einfluss des Menschen. Ber. ü. Landwirtschaft, 50 (1): 112-139. (in German)

Turski R., Uziak S., Zawadzki S., 1993. Gleby. Środowisko przyrodnicze Lubelszczyzny. / Soils. The natural environment of the Lublin region. LTN, Lublin. (in Polish)

Witosławski P., 2006. Atlas of distribution of vascular plants in Łódź. Wydawnictwo Uniwersytetu Łódzkiego, Łódź.

Wrzesień M., Święs F., 2006. Flora i zbiorowiska roślin naczyniowych terenów kolejowych zachodniej części Wyżyny Lubelskiej. / The flora and communities of vascular plants in the railway areas in the western part of the Lublin Upland. Wydawnictwo UMCS, Lublin. (in Polish)

Zają c A., 1978. Atlas of distribution of vascular plants in Poland (ATPOL). Taxon, 27 (5/6): 481-484.

Zając M., Zając A., 1992. A tentative list of segetal and ruderal apophytes in Poland. Zesz. Nauk. Uniw. Jagiellońskiego, Pr. Bot., 24: 7-23.

Zając A., Tokarska-Guzik B., 1998. Kenophytes in the flora of Poland: list, status and origin. [In:] Synanthropization of plant cover in new Polish research. Phytocenosis 10 (N. S.) Suppl. Cartogr. Geobot. 9: 107-116.

Zarzycki K., Trzcińska-Tacik H., Różański W., Szeląg Z., Wołek J., Korzeniak U., 2002. Ecological indicator values of vascular plants of Poland. W. Szafer Institute of Botany, Polish Academy of Sciences, Kraków, 1-183.

Zinkiewicz W., Warakomski W., 1959. Zarys klimatu Lublina. Ann. UMCS sect. B, 14: 47-131. (in Polish) 
Udział gatunków kserotermicznych we florze roślin naczyniowych Lublina, Polska

Streszczenie

Przedmiotem pracy jest prezentacja rozmieszczenia i charakterystyka flory kserotermicznej zlokalizowanej na terenie Lublina w jego granicach administracyjnych.

Dane na temat badanej flory zostały zaczerpnięte z literatury, notowań zielnikowych oraz zebrane podczas badań terenowych prowadzonych w latach 2002-2009. Charakterystyka flory zawiera następujące dane: przynależność do rodziny, formę życiową, skalę synantropizacji gatunku i siedliska, kategorie zagrożenia i ochronę gatunkową. $\mathrm{Na}$ terenie $\mathrm{Lu}-$ blina opisano 107 gatunków roślin kserotermicznych należących do 26 rodzin i 70 rodzajów. Stanowi to $10 \%$ flory miasta. Najliczniej reprezentowane były taksony z klasy Festuco-Brometea (70), liczba gatunków w klasie Trifolio-Geranietea sanguinei wynosiła 21, natomiast w Rhamno-Prunetea 16. Ośmiu gatunków wcześniej notowanych nie odnaleziono podczas badań terenowych, należały one do klasy Festuco-Brometea. W spektrum form życiowych dominują hemikryptofity (57 gatunków) i fanerofity (14), pod względem grup geograficzno-historycznych gatunki rodzime (103) zdecydowanie dominują nad obcymi (4). Wśród gatunków kserotermicznych Lublina opisano 21 roślin chronionych i zagrożonych. Rozmieszczenie gatunków na terenie miasta jest mozaikowe. Frekwencja, mierzona obecnością gatunku w podstawowym polu badawczym, waha się od 1 do 44. Analiza rozmieszczenia i danych historycznych wskazuje dwie przyczyny takiego stanu: zmienna wartość RIH w poszczególnych polach badawczych oraz historia flory danego obszaru. Gatunki kserotermiczne na terenie miasta koncentrują w miejscach najmniej antropogenicznie przekształconych oraz $\mathrm{w}$ pobliżu płatów roślinności kserotermicznej opisywanych od początku XX wieku. 